\title{
Pembekalan Kompetensi Siswa Mengikuti Uji Kompetensi Bidang Multimedia bagi Siswa SMKN 1 Payung
}

\author{
Hamidah¹, Okkita Rizan ${ }^{2}$, Sujono ${ }^{3}$, Harrizki Arie Pradana ${ }^{4}$ \\ hamidah@atmaluhur.ac.id ${ }^{1}$, orizan@atmaluhur.ac.id ${ }^{2}$, sujono@atmaluhur.ac.id ${ }^{3}$, \\ harrizkiariep@atmaluhur.ac.id ${ }^{4}$ \\ 1,2,3,4 ISB Atma Luhur
}

\author{
Article History: \\ Received: 07-06-2021 \\ Revised: 16-6-2021 \\ Accepted: 22-6-2021
}

\begin{abstract}
:
Technological developments are increasingly developing. This requires students to improve skills in the field of multimedia to assist in dealing with school competency tests. All students are expected to be able to take the test and are required to pass as one of the graduation requirements. In this pandemic era, learning activities were a little disrupted so that it demanded that the school provide maximum provision for students. SMKN 1 Payung students still do not understand how to apply multimedia. Based on the above problems, it is necessary to provide provision on multimedia so that students are ready to face school competency exams. Some applications that can be used as a tool for creating multimedia are the Corel Draw $X 7$ application specifically for designing multimedia and Adobe Illustrator for creating animations. The method used in this provision is direct multimedia design practice. It is expected that this debriefing activity can improve the abilities of all students in facing competency tests so that they can graduate on time.
\end{abstract}

Keywords: Multimedia, technology, competency

\section{Pendahuluan}

Perkembangan teknologi yang semakin meningkat dalam berbagai bidang kehidupan pada saat ini menuntut masyarakat luas untuk memahami teknologi. Penggunaan teknologi merambah semua bidang yang berada dalam kehidupan sehari-hari, masyarakat dituntut mengetahui dan mampu menggunakan komputer dan internet secara baik dan memiliki pemahaman baik mengenai penggunaan teknologi tersebut. Penggunaan teknologi dalam dunia pendidikan tentu saja mampu meningkatkan prestasi belajar siswa (Ahmad Yani et al., 2020).

Perkembangan ilmu pengetahuan dan teknologi semakin pesat sehingga menuntut dunia pendidikan untuk terus meningkatkan mutu pendidikan. Sekolah Menengah Kejuruan adalah lembaga formal berbeda dengan sekolah menengah atas. Hal ini dikarenakan sekolah menengah kejuruan dituntut menghasilkan lulusan yang memiliki keterampilan yang menjadikan lulusan yang siap kerja atau terjun ke lapangan. Keterampilan yang dimaksud adalah keterampilan praktek yang dilakukan siswa secara langsung. Pendidikan menengah kejuruan berfungsi untuk mempersiapkan lulusannya yang memiliki ketrampilan memadai untuk menjadi tenaga kerja siap pakai dan trampil (Irwanti \& Sudira, 2014). Salah satu 
upaya pemerintah dalam meningkatkan pengetahuan dan keterampilan siswa khususnya untuk Sekolah Menengah Kejuruan (SMK) adalah dengan menyelenggarakan ujian kompetensi keahlian yang menjadi penentu bagi kelulusan siswa. Berdasarkan Laurentinus et al. (2021) fungsi dari penilaian hasil belajar adalah untuk (1) mengukur tingkat capaian hasil belajar/kompetensi siswa; (2) mengukur pertumbuhan dan perkembangan siswa; (3) mendiagnosis kesulitan belajar siswa; (4) mengukur efektivitas proses pembelajaran; dan (5) mengukur pencapaian kurikulum. Ujian kompetensi keahlian merupakan salah satu bentuk Ujian Nasional (UN) yang diselenggarakan oleh Pemerintah Pusat (Noviandani et al., 2016). Maka dari itulah pihak sekolah tidak sungkan untuk mencarikan pembimbing khusus untuk membimbing para siswa dalam menyelesaikan suatu kasus/permasalahan yang berhubungan dengan ujian kompetensi keahlian (Putra et al., 2020).

Kompetensi adalah suatu kemampuan untuk melaksanakan atau melakukan suatu pekerjaan atau tugas yang dilandasi atas keterampilan dan pengetahuan serta didukung oleh sikap kerja yang dituntut oleh pekerjaan tersebut. (Purnama \& Awalin, 2020). Menurut Syah et al. (2017) kompetensi merupakan perpaduan dari pengetahuan, keterampilan, nilai, dan sikap yang direfleksikan dalam kebiasaan berpikir dan bertindak (Setiawati \& Sudira, 2015). Penelitian ini sebelumnya dilakukan oleh Putra et al. (2020) yang menyatakan bahwa indikator keberhasilan dalam melakukan pelatihan persiapan uji kompetensi keahlian ini tidak hanya dilihat dari penilaian siswa saja, akan tetapi yang lebih penting adalah kerjasama yang terjalin secara terus menerus antara sekolah mitra dengan pihak universitas. Kegiatan UKK adalah sebuah aktivitas pendidikan yang sangat strategis untuk mengungkap capaian kompetensi siswa (Saptono et al., 2020). Penilaian untuk mengetahui siswa SMK kompeten atau tidak dilakukan melalui Ujian Kompetensi Keahlian (UKK) (Syah et al., 2017).

Untuk mengetahui penguasaan teknik pembuatan produk multimedia pada siswa SMK dengan kompetensi keahlian multimedia, perlu dilakukan pengujian. Uji kompetensi keahlian multimedia dilakukan untuk mengetahui penguasaan siswa terhadap teknik-teknik pembuatan efek yang ada pada perangkat lunak multimedia, dan kreatifitas siswa dalam membuat produk multimedia sesuai dengan topik yang diberikan (Widodo, 2019). Berdasarkan uraian diatas, maka permasalahan yang dihadapi siswa SMKN 1 Payung adalah kurang menguasai multimedia dalam menghadapi ujian kompetensi sebagai salah satu syarat kelulusan. Hal ini mendorong tim pengabdian untuk memberikan pembekalan kepada siswa dalam mempelajari multimedia sehingga dapat dengan mudah lulus ujian praktek. Adapun materi yang diajarkan adalah mengenai penggunaan tools aplikasi multimedia, studi kasus penerapan multimedia, dan membuat animasi. 


\section{Metode}

Ada beberapa metode yang digunakan dalam kegiatan pengabdian pembekalan siswa dalam menghadapi ujian kompetensi, yaitu tahap persiapan, tahap pelaksanaan dan tahap evaluasi.

1) Tahap Pelaksanaan

Pada tahap ini secara garis besar metode pelaksanaan kegiatan pengabdian dilakukan dalam 3 tahap, yaitu persiapan, pemberian materi dan evaluasi. Adapun metode dapat dilihat pada gambar 1 dibawah ini :



Gambar 1. Metode pengabdian

2) Tim Pelaksana

Adapun beberapa orang yang terlibat dan membantu dalam kegiatan pengabdian ini antara lain dosen dan mahasiswa. Adapun anggota tim sebagai berikut :

$\checkmark$ Hamidah, M. Kom

$\checkmark$ Okkita Rizan, M. Kom (Dosen)

$\checkmark$ Sujono, M. Kom (Dose)

$\checkmark$ Harrizki Arie Pradana, M. Kom (Dosen)

$\checkmark 2$ Orang Mahasiswa

3) Jadwal dan Waktu Pelaksanaan

Adapun lokasi pelaksanaan kegiatan pengabdian adalah Laboratorium SMKN 1 Payung Kecamatan Payung Kabupaten Bangka Selatan Propinsi Kepulauan Bangka Belitung. Kegiatan pengabdian dilakukan selama 2 (dua) hari, terhitung mulai tanggal $6-7$ 
April 2021. Berikut susunan kegiatan pengabdian sebagai berikut:

Tabel 1. Jadwal kegiatan pengabdian kepada masyarakat

\begin{tabular}{lll}
\hline \multicolumn{1}{c}{ Waktu } & \multicolumn{1}{c}{ Kegiatan } & \multicolumn{1}{c}{ Pemateri } \\
\hline $\begin{array}{l}\text { Hari Pertama: } \\
\text { Pukul 08.00 s/d } 12.00\end{array}$ & $\begin{array}{l}\text { Penyampaian materi dasar } \\
\text { tentang multimedia }\end{array}$ & $\begin{array}{l}\text { Hamidah } \\
\text { Okkita Rizan }\end{array}$ \\
\hline Pukul 13.00 s/d 16.00 & $\begin{array}{l}\text { Praktek penggunaan tools } \\
\text { multimedia }\end{array}$ & $\begin{array}{l}\text { Sujono } \\
\text { Harrizki Arie Pradana }\end{array}$ \\
\hline $\begin{array}{l}\text { Hari Kedua: } \\
\text { Pukul 08.00 s/d 12.00 }\end{array}$ & $\begin{array}{l}\text { Praktek membuat konten } \\
\text { multimedia sesi 1 }\end{array}$ & $\begin{array}{l}\text { Sujono } \\
\text { Hamidah }\end{array}$ \\
\hline $\begin{array}{l}\text { Pukul } 13.00 \text { s/d } 16.00 \\
\end{array}$ & $\begin{array}{l}\text { Praktek membuat konten } \\
\text { multimedia sesi 2 } \\
\text { Evaluasi }\end{array}$ & $\begin{array}{l}\text { Okkita Rizan } \\
\text { Harrizki Arie Pradana }\end{array}$ \\
\hline
\end{tabular}

\section{Pembahasan}

Kegiatan pembekalan dilakukan selama 2 (dua) hari di Laboratorium Multimedia SMKN 1 Payung yang dihadiri oleh sebanyak 21 Orang siswa. Pelatihan tersebut berjalan baik dan lancar. Kegiatan dibagi kedalam 2 sesi dalam satu hari yang dapat dilihat pada tabel jadwal di atas. Kegiatan pada hari pertama yaitu penyampaian materi tentang multimedia yang dimulai pada pukul $08.00 \mathrm{~s} / \mathrm{d} 12.00$ kepada seluruh siswa dan diselingi dengan sesi tanya jawab tentang multimedia.

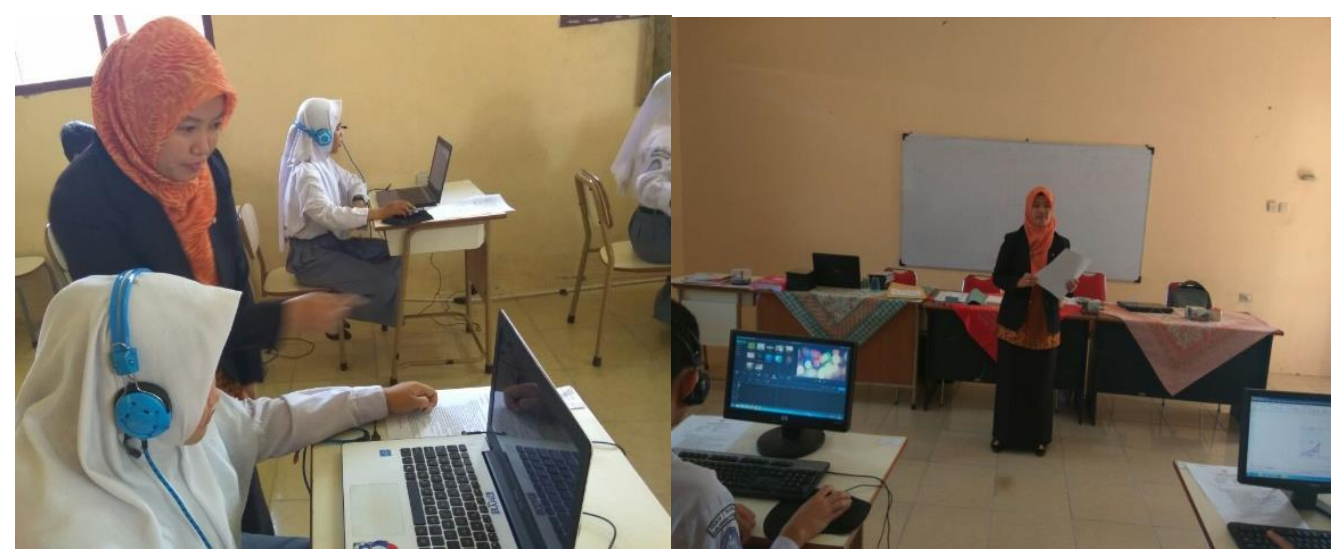

Gambar 2. Penyampaian materi

Selanjutnya pada sesi ke-2 pada siang hari pukul $13.00 \mathrm{~s} / \mathrm{d} 16.00$ dilanjutkan dengan siswa praktek langsung membuat logo dari memilih bentuk,memasukkan teks, memilih warna serta mengexport logo kedalam format gambar. Praktek langsung diarahkan oleh tim dengan memberi studi kasus tentang multimedia kepada siswa dan dijelaskan secara step by step. Siswa langsung mengikuti tutor dan praktek langsung. Jika siswa ada kesulitan, maka anggota tim akan langsung membantu siswa tersebut. Anggota tim akan mengajarkan siswa sampai mereka paham dan mengerti. 


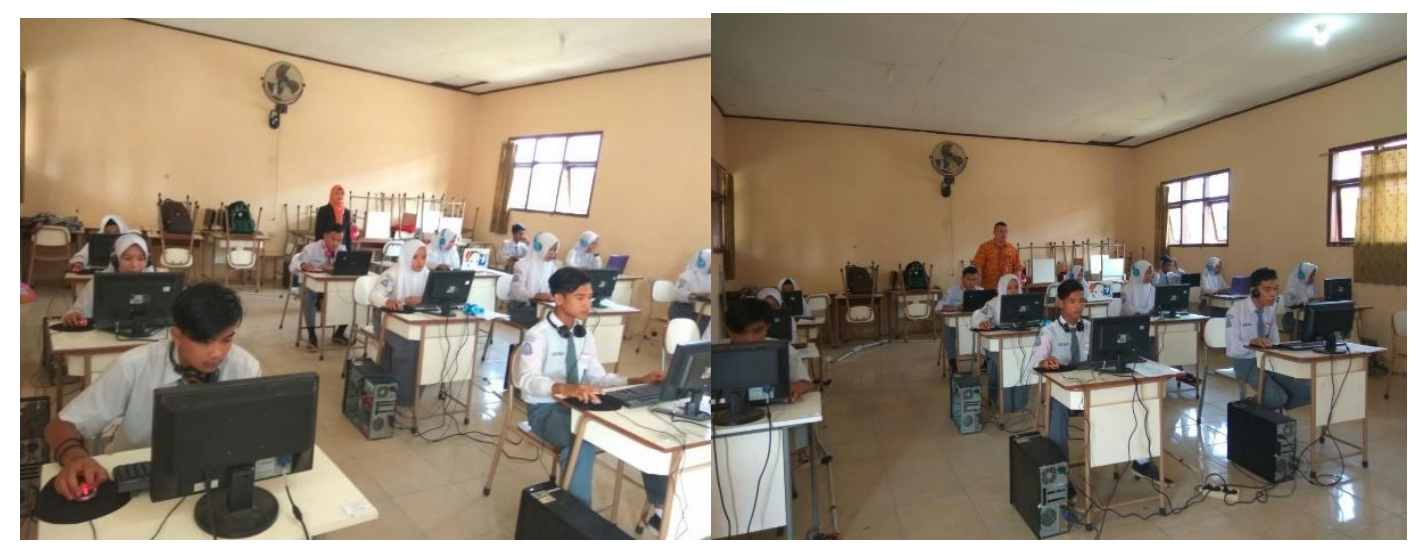

Gambar 3. Siswa praktek langsung

Kegiatan pada hari kedua sesi pertama, dari pukul $08.00 \mathrm{~s} / \mathrm{d} 12.00$ siswa diajarkan praktek membuat spanduk, antara lain mendesain bentuk spanduk, menambah teks serta memilih warna dan membuat animasi bergerak. Pada sesi ke-2 hari kedua, dilakukan evaluasi setiap siswa dengan cara memberi studi kasus sesuai dengan konsep yang telah diajarkan dalam pelatihan. Siswa sangat senang dan antusia sekali mengikuti pelatihan tersebut. Mereka sering mengajukan pertanyaan jika ada yang dirasa kurang mengerti sampai anggota tim kewalahan mengajari siswa. Pada sesi terakhir hari kedua, dilakukan evaluasi dengan memberikan studi kasus. Hal ini dilakukan untuk mengukur sejauh mana pemahaman siswa tentang multimedia selama mengikuti pelatihan.

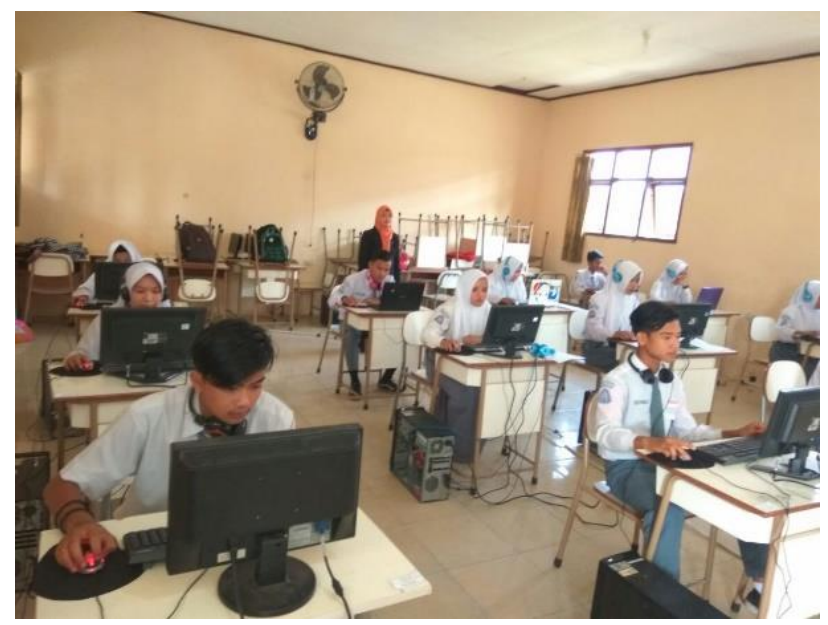

Gambar 4. Foto dokumentasi pengabdian

Berdasarkan hasil praktek nilai pengetahuan yang diberikan kepada siswa, maka dapat disimpulkan bahwa ada peningkatan kompetensi keahlian siswa mengalami peningkatan yang signifikan. Hal ini dibuktikan dari hasil praktek yang dihasilkan setiap siswa. Berikut hasil praktek pelatihan kompetensi keahlian siswa selama mengikuti kegiatan pelatihan: 
Tabel 2. Hasil praktek nilai pengetahuan

\begin{tabular}{lc}
\hline \multicolumn{1}{c}{ Deskripsi } & $\begin{array}{c}\text { Rata-rata } \\
\text { Capaian }\end{array}$ \\
\hline $\begin{array}{l}\text { Melakukan pekerjaan dengan gambar } \\
\text { digital }\end{array}$ & 80 \\
\hline Membuat desain grafis multimedia 2D & 85 \\
\hline $\begin{array}{l}\text { Menggabungkan fotografi digital kedalam } \\
\text { multimedia }\end{array}$ & 85 \\
\hline $\begin{array}{l}\text { Melakukan pekerjaan dengan gambar } \\
\text { digital }\end{array}$ & 87 \\
\hline $\begin{array}{l}\text { Menciptakan desain grafik Multimedia 2D } \\
\text { Menggabungkan foto digital kedalam }\end{array}$ & 86 \\
\hline $\begin{array}{l}\text { rangkaian multimedia } \\
\text { Menampilkan karya seni digital 2D }\end{array}$ & 80 \\
\hline
\end{tabular}

Berdasarkan hasil rata-rata capaian diatas, nilai tersebut sudah melewati batas minimum standar syarat kelulusan kompetensi keahlian siswa nasional. Untuk itu, berdasarkan hasil diatas, maka dapat disimpulkan bahwa pelatihan sudah memenuhi nilai rata-rata capaian kompetensi yang dapat dilihat pada grafik dibawah ini :



Gambar 5. Grafik hasil praktek nilai pengetahuan

\section{Kesimpulan}

Dalam pelaksanaan pembekalan siswa dalam menghadapi ujian kompetensi dapat disimpulkan berjalan dengan baik dan lancar. Kegiatan pelatihan tersebut berjalan sesuai dengan rencana walaupun masih ada beberapa sedikit kekurangan sana sini. Diharapkan dengan adanya pelatihan tersebut, maka akan dapat membantu dan memberi kemudahan kepada siswa dalam bidang multimedia dalam menghadapi ujian kompetensi keahlian sekolah sehingga mendapatkan hasil yang maksimal serta dapat meningkatkan kompetensi 
masing-masing siswa.

\section{Ucapan Terimakasih}

Ucapan terima kasih kami hanturkan kepada ISB Atma Luhur selaku pelindung dalam kegiatan pelatihan ini. Selain itu, tak lupa pula kepada Ketua LPPM ISB Atma Luhur beserta jajarannya yang telah membantu terselenggaranya kegiatan ini serta Kepala Sekolah SMKN 1 Payung yang telah bekerja sama dalam kegiatan pelatihan ini.

\section{Daftar Pustaka}

Yani, A., Anoi, Y.H. , \& Hamdani, W. (2020). Pelatihan Peningkatan Kompetensi Pra Uji Kompetensi Kejuruan (UKK) Jurusan Teknik Otomotif Kepada Siswa Smk Rigomasi Bontang. Jurnal Abdimas Bina Bangsa. Https://doi.org/10.46306/jabb.v1i1.48

Irwanti, Y. D., \& Sudira, P. (2014). Evaluasi Uji Kompetensi Siswa Keahlian Multimedia Di SMK SeKota Yogyakarta. Jurnal Pendidikan Vokasi. Https://doi.org/10.21831/jpv.v4i3.2564

Laurentinus, L., Rizan, O., Hamidah, H., \& Sarwindah, S. (2021). Digitalisasi UMKM Berbasis Retail Melalui Program Hibah Ristek-Brin. To maega: Jurnal Pengabdian Masyarakat. Https://doi.org/10.35914/tomaega.v4i1.418

Noviandani, P., Purnawan, P., \& Wardaya, W. (2016). Analisis Hasil Kerja Pada Uji Kompetensi Praktik Kejuruan Teknik Pemesinan Siswa SMK. Journal of Mechanical Engineering Education. Https://doi.org/10.17509/jmee.v1i2.3819

Purnama, M. A., \& , Fischa A, z. M. S. (2020). Pelatihan Efikasi Diri terhadap Penurunan Kecemasan Siswa - Siswi SMK Kesehatan Bina Prestasi Tangerang dalam Menghadapi Ujian Kompetensi Kejuruan. 3(2), 66-71.

Putra, Y. K., Sadali, M., Fathurrahman, F., \& Mahpuz, M. (2020). Pelatihan Uji Kompetensi Keahlian Siswa Sekolah Kejuruan Menggunakan Metode Participatory Learning and Action (PLA). Absyara: Jurnal Pengabdian Pada Masyarakat. Https://doi.org/10.29408/ab.v1i2.2772

Saptono, Arcelinus, P., Waliulu, R. F., \& Mandela, W. (2020). Pelatihan Siswa untuk Menghadapi Ujian Kompetensi. 1(2), 37-41.

Setiawati, I., \& Sudira, P. (2015). Faktor-faktor yang Mempengaruhi Prestasi Belajar Teknik Komputer dan Informatika. Jurnal pendidikan vokasi.

Syah, I. U., Sumirat, U., \& Purnawan, P. (2017). Pencapaian Kompetensi Siswa SMK dalam Praktik Bekerja dengan Mesin Bubut. Journal of Mechanical Engineering Education. Https://doi.org/10.17509/jmee.v4i1.7443

Widodo, Y. B. (2019). Pengujian Kompetensi Keahlian Multimedia di SMK Jakarta Raya 3. Jurnal Pemberdayaan Komunitas Mh Thamrin. Https://doi.org/10.37012/jpkmht.v1i1.377 
